\section{Tolerance of Cucurbits to the Herbicides Clomazone, Ethalfluralin and Pendimethalin. II. Watermelon}

\author{
Timothy L. Grey ${ }^{1}$, David C. Bridges ${ }^{2}$, and D. Scott NeSmith ${ }^{3}$ \\ College of Agricultural and Environmental Sciences, University of Georgia, \\ Georgia Station, 1109 Experiment Street, Griffin, GA 30223-1797
}

Additional index words. Citrullus lanatus, vegetable crops, injury, weed control, yield, susceptibility to herbicides

\begin{abstract}
Field studies were conducted in 1993, 1994, and 1995 to determine tolerance of seeded and transplanted watermelon [Citrullus lanatus (Thunb.) Matsum and Nak.] to clomazone, ethalfluralin, and pendimethalin using method of stand establishment (directseeded vs. transplanted) and time of herbicide application [preplant soil incorporated (PPI), preplant to the surface (PP), or postplant to the surface (POP)] as variables. Yield and average fruit weight in plots with clomazone were equal to or greater than those in control plots for the 3-year study regardless of method of application. Bleaching and stunting were evident with clomazone in early-season ratings, but injury was transient and did not affect quality or yield. Of the three herbicides, ethalfluralin PPI resulted in the greatest injury, stand reduction, and yield reduction of the three herbicides. Pendimethalin (PPI, PP, or POP) reduced yield of direct-seeded but not of transplanted watermelon. Chemical names used: 2-[(-2-chlorophenyl)methyl]-4, 4-dimethyl-3-isoxazolidinone (clomazone); $N$-ethyl- $N$-(2-methyl-2-propenyl)-2,6-dinitro-4-(trifluoromethyl) benzenamine (ethalfluralin); $N$-(1-ethylopropyl)-3,4-dimethyl-2,6-dinitrobenzenamine (pendimethalin).
\end{abstract}

Watermelon consistently ranks as the most commonly planted vegetable crop in Georgia, with over 13,528 ha in 1998 (Mizelle, 1999). Georgia accounted for $16 \%$ of the 1.9 million $\mathrm{t}$ of U.S. commercial production in 1997 (U.S. Dept. of Agriculture, 1999). Triploid (seedless) watermelon production has increased rapidly because of marketability (Monks and Schultheis, 1998). However, seed for triploid watermelon and other premium cultivars are expensive. In order to reduce cost of overseeding, growers often use transplants.

Weed control programs can differ considerably for seeded vs. transplanted watermelon. Growers choose transplanting over direct seeding because of more uniform plant spacing and stand, earlier harvest, and more efficient use of expensive seeds (Mitchem et al., 1997). Polyethylene bed covers were used to help control pests on 32\% of the State's hectarage in 1998 (Mizelle, 1999), with the remainder in bareground production. A limited number of her-

Received for publication 21 June 1999. Accepted for publication 12 Nov. 1999. We thank D. Barry, W. Slaughter, R. Rivers, and E. Moncrief for their contributions. Statistical services were provided by J. Davis, Experimental Statistics, Univ. of Georgia, Griffin Campus. This research was conducted with State and Hatch funds allocated to the authors research projects and by gifts and grants from various industry sources. The cost of publishing this paper was defrayed in part by the payment of page charges. Under postal regulations, this paper therefore must be marked advertisement solely to indicate this fact.

${ }^{1}$ Assistant Research Scientist, Dept. of Crop and Soil Sciences. E-mail address: tgrey@gaes. griffin.peachnet.edu

${ }^{2}$ Professor, Dept. of Crop and Soil Sciences.

${ }^{3}$ Professor, Horticulture Research Center. bicides are available for weed control in bareground or polyethylene-covered bed production. Major yield losses in watermelon can be caused by weeds that emerge after rapidly growing vines prevent cultivation (Menges et al., 1973).

The four herbicides widely used in watermelon production are: bensulide $\{O, O$ bis(1-methylethyl) $S$-[2-[(phenylsulfonyl) amino]ethyl] phosphorodithioate $\}$, naptalam [sodium 2-[(1-naphthalenylamino)carbonyl] benzoate], and ethalfluralin for residual weed control; and sethoxydim \{2-[1-(ethoxyimino) butyl]-5-[2-(ethylthio)propyl]-3-hydroxy-2cyclohexen-1-one $\}$ for postemergence control of annual grasses (Ahrens, 1994). Bensulide is either incorporated into the soil preplant (PPI) or applied to the soil surface after planting and then watered (irrigated) in. Bensulide primarily controls annual grasses and small-seeded broadleaf weeds but is not effective on large-seeded dicot species (Glaze, 1975). Bensulide can be persistent in the soil, resulting in injury to small grains when they are planted in rotation with watermelon within 5 months after treatment (Menges et al., 1973). Naptalam is active on several dicot species and annual grasses. However, rainfall must be ideal to achieve adequate weed control Insufficient rain limits herbicide movement into the soil, resulting in poor weed control; excessive rainfall causes the herbicide to leach in coarse soils, leading to erratic performance (Monaco and Skrock, 1980). The current label states that bensulide and naptalam can be tank-mixed and prepplant soil incorporated (PPI), but this treatment is expensive.

Ethalfluralin, the most commonly used herbicide in Georgia watermelon production, in- jured emerging seedlings, reduced seedling vigor, and reduced yield of seeded and transplanted watermelon when applied PPI or preemergence (PRE) in North Carolina (Mitchem et al., 1997). Less injury (3\%) occurred when ethalfluralin was applied postemergence over the top of plants immediately after transplanting than when PPI(Mitchem et al., 1997). Darmstadt (1979) reported 7\% root injury with ethalfluralin at $1.4 \mathrm{~kg} \cdot \mathrm{ha}^{-1}$ a.i. when applied PP followed by $1.9 \mathrm{~cm}$ of irrigation. Several studies have reported differences in response among cultivars (Eshel and Shlevin, 1973), stunting, and yield reduction in watermelon following application of dinitroanaline herbicides (Darmstadt, 1979; Mitchem, et al., 1997; Monaco and Skroch, 1980). Few herbicides are available for weed control in cucurbit production (Kupatt et al., 1983), limiting the use of conservation tillage practices (NeSmith et al., 1994). Pendimethalin, a dinitroanaline herbicide, is registered for use in several agronomic crops to control grasses and small-seeded dicots, but has not been adequately evaluated for use in Georgia watermelon production.

Clomazone is a soil-applied herbicide that is currently registered for use in soybean [ Glycine $\max$ (L.) Merrill], bell pepper (Capsicum annuum L.), tobacco (Nicotianum tabacum L.), pumpkin (Cucurbita pepo L.), and processing squash (Cucurbita pepo L.) (Barth et al., 1995). Clomazone offers application versatility (Langston et al., 1997) and control of prickly sida (Sida spinosa L.), jimsonweed (Datura stramonium L.), Florida beggarweed [Desmodium tortuosum (Sw.) DC.], small flowered morning glory (Jacquemontia tamnifolia L.), velvetleaf(Abutilon theophrasti Medik), and spurred anoda [Anoda cristata (L.) Schlecht] (Ahrens, 1994), all of which can be troublesome weeds in the southeastern United States. While field studies have indicated that clomazone may provide full-season preemergence weed control in selected cucurbits, differential phytotoxicity and sensitivity between cucurbits may be cultivar-specific (Barth et al., 1995; Frost et al., 1983).

Having a limited number of herbicide options can lead to inadequate weed control, which complicates harvest and may reduce yield and quality of watermelon. Also, the method of establishing watermelon stands may affect herbicide injury. If additional herbicides could be registered for use in watermelon, or alternative methods of application could be developed for currently registered herbicides, the economics of watermelon production could be improved. The objectives of this investigation were to determine: 1) the tolerance of field-grown watermelon to clomazone, ethalfluralin and pendimethalin;2) the effect of application timing on crop tolerance and yield; and 3) the effect of establishment method (seeded vs. transplanted plots) on watermelon tolerance to these herbicides.

\section{Materials and Methods}

Studies were conducted in 1993, 1994, and 1995 at the Southwest Georgia Branch Experiment Station near Plains, Ga., on a Faceville 
sandy loam (clayey, kaolinitic, thermic, Typic Kandiudults) with $71 \%$ sand, $13 \%$ silt, $16 \%$ clay, $1 \%$ organic matter, and $6.0 \mathrm{pH}$. Transplants ('Royal Sweet') were grown in a greenhouse in commercial potting media using plastic bedding trays. Seedlings remained in the greenhouse for 4 weeks before being transplanted into the field. Plants were established in the field by either direct hand seeding $(2.5 \mathrm{~cm}$ into soil) or hand transplanting $(4.0 \mathrm{~cm}$ into soil) seedlings on the same day. Planting dates were 29 Apr. 1993, 15 Apr. 1994, and 3 May 1995 following conventional tillage by moldboard plowing and smoothing using a rotary tiller. The experimental design was a factorial arrangement of treatments within a randomized complete-block with four replications (blocks) with an individual row (3.6-m wide $\times 7.6-\mathrm{m}$ long) within a plot. Target stand for both seeded and transplanted watermelon was 0.6 plants per $\mathrm{m}^{2}$, which was achieved in the controls (seeded and transplanted) and served as the basis for determination of percentage of stand reduction.

Irrigation was applied as needed by the crop, and fertilizer was applied based on Univ. of Georgia soil test recommendations for watermelon production. Insects were monitored and carbaryl (1-napthyl $\mathrm{N}$ methylcarbamate) insecticide was applied when necessary (MacDonald, 1999). Plots were maintained weed-free throughout the course of the study.

The herbicides evaluated (all concentrations expressed as a.i.) were clomazone emulsifiable concentrate [(EC) $0.5 \mathrm{~kg} \cdot \mathrm{ha}^{-1}$, ethalfluralin [(EC) $0.4 \mathrm{~kg} \cdot \mathrm{ha}^{-1}$, and pendimethalin $\left[(\mathrm{EC}) 0.5 \mathrm{~kg} \cdot \mathrm{ha}^{-1}\right]$. The herbicide treatments were applied to either seeded or transplanted watermelon as follows: 1) clomazone EC $0.8 \mathrm{~kg} \cdot \mathrm{ha}^{-1}$; 2) ethalfluralin EC $1.3 \mathrm{~kg} \cdot \mathrm{ha}^{-1}$; 3) pendimethalin EC $0.84 \mathrm{~kg} \cdot \mathrm{ha}^{-1}$; and 4) nontreated control. Herbicides were applied PPI, surface applied before seeding or transplanting (PP), and surface applied after seeding or transplanting (POP). All treatments were applied on the day of planting or transplanting. The PPI treatments were incorporated to a depth of $2.5 \mathrm{~cm}$ with a power tiller. Herbicides were applied with a backpack sprayer calibrated to deliver $187 \mathrm{~L} \cdot \mathrm{ha}^{-1}$ at $210 \mathrm{kPa}$.

Stand reduction counts were made based on the initial stand in comparison with the nontreated control for seeded and transplanted plots on a scale of $0 \%$ (no reduction) to $100 \%$ (complete reduction). Bleaching and stunting were visually estimated using a scale of $0 \%$ (no injury) to $100 \%$ (crop death). Stand counts were made in 1993 and 1994, and culled melon (nonmarketable melons) counts were made during harvest in 1994 and 1995. Bleaching, stunting, and stand reduction counts, when applicable, were made on 14 May 1993, 28 Apr. 1994, and 18 May 1995. Marketable fruit were harvested 13 July 1993, 12 July 1994, and 31 July 1995, counted, and individually weighed. Watermelon number/ha, yield, and average weight were determined.

All data were subjected to analysis of variance (ANOVA) and tested for yearby-treatment interactions. Treatment means were separated with appropriate Fisher's protected least significant difference test (LSD) at $P \leq 0.05$.

\section{Results and Discussion}

ANOVA of the data revealed treatment $x$ year interactions. These factors prevented the pooling of data across years. Therefore, the data are presented for each year.

\section{Stand reduction}

Plots were seeded and transplanted equally, reductions in stand in the nontreated control are a reflection of nonemergence of seed, or death of transplanted seedlings. Percentage of reduction of stands was not normalized to fit the nontreated controls to zero (Table 1).

Clomazone EC. Stand of seeded plots was unaffected by clomazone PPI, PP, or POP(Table 1), although some minor, but inconsistent, stand reduction of transplanted watermelon was observed with clomazone PP and POP. The PP treatment in 1995 significantly reduced stand of transplants. Weston and Jones (1990) reported that transplanted bell pepper and sweet potato (Ipomoea batatas L.) slips (Porter, 1990) showed injury from clomazone POP, but this injury was transient and yield was unaffected.

Ethalfluralin. Ethalfluralin PPI and PP often reduced the stand of seeded plots (Table 1). PPI treatments reduced stands by $94 \%, 100 \%$, and $50 \%$ and PP treatments reduced them by $98 \%, 100 \%$, and $0 \%$ during 1993, 1994, and 1995 , respectively. Variation of stand reduction $(0 \%$ to $100 \%$ ) with ethalfluralin PP indicates the variability of this treatment in watermelon, as previously noted by Mitchem et al. (1997). Severe injury and/or stand reduction often occurs when dinitroaniline herbicides are applied PRE to seeded cucurbit crops because of root and shoot damage (Darmstadt, 1979; Eshel and Shlevin, 1973; Menges et al., 1973). Incorporation into the soil increases exposure of the seedling to herbicides by dispersing them throughout the seedbed. POPseeding treatments were generally less injurious than PP or PPI treatments. With the PP treatments, treated soil was often moved to the seed zone during the seeding process, increasing the potential for radical and hypocotyl exposure to the herbicide during emergence. Similar results have been observed with other cucurbits (Kupatt et al., 1983). Movement of soil with the PP treatments also may move nontreated soil into the furrow, which could reduce weed control. In 1993 and 1995, no significant injury occurred following POP treatment of seeded plots with ethalfluralin.

Stand of transplanted watermelon was unaffected by ethalfluralin PPI, PP, or POP, except for the 1995 PPI treatment (50\%). Mitchem et al. (1997) reported significant injury to 'Royal Sweet' watermelon seedlings

Table 1. Stand reduction and stunting (\%) of seeded and transplanted watermelon as influenced by $\mathrm{PPI}^{\mathrm{z}}$, $\mathrm{PP}^{\mathrm{z}}$, and POP${ }^{\mathrm{z}}$ application of herbicides at Plains, Ga., 1993-1995.

\begin{tabular}{|c|c|c|c|c|c|c|c|c|c|c|c|}
\hline \multirow[b]{3}{*}{ Planting method } & \multirow[b]{3}{*}{ Herbicide } & \multirow{3}{*}{$\begin{array}{c}\text { Rate of application } \\
\left(\mathrm{kg} \cdot \mathrm{ha}^{-1} \text { a.i. }\right)\end{array}$} & \multicolumn{8}{|c|}{ Herbicide application } & \\
\hline & & & \multicolumn{3}{|c|}{ PPI } & \multicolumn{3}{|c|}{$\mathrm{PP}$} & \multicolumn{3}{|c|}{ POP } \\
\hline & & & 1993 & 1994 & 1995 & 1993 & 1994 & 1995 & 1993 & 1994 & 1995 \\
\hline & & & \multicolumn{9}{|c|}{$\%$ Stand reduction } \\
\hline & Ethalfluralin & 1.3 & $94 \mathrm{a}$ & $100 \mathrm{a}$ & $50 \mathrm{a}$ & $98 \mathrm{a}$ & $100 \mathrm{a}$ & 0 & 5 & 47 & 3 \\
\hline & Pendimenthalin & 0.84 & $28 \mathrm{~b}$ & $41 \mathrm{~b}$ & $25 \mathrm{a}$ & $84 \mathrm{a}$ & $91 \mathrm{a}$ & 30 & 3 & 28 & 0 \\
\hline \multirow{3}{*}{ Transplanted } & Nontreated & & $0 \mathrm{c}$ & $28 \mathrm{~b}$ & $0 \mathrm{~b}$ & $0 \mathrm{~b}$ & $28 \mathrm{~b}$ & 0 & 0 & 28 & 0 \\
\hline & Clomazone & 0.8 & 0 & 0 & $14 \mathrm{~b}$ & 0 & 25 & $30 \mathrm{a}$ & 0 & 25 & 21 \\
\hline & Nontreated & & 0 & 0 & $16 \mathrm{~b}$ & 0 & 0 & $0 \mathrm{~b}$ & 0 & 0 & 16 \\
\hline \multirow[t]{4}{*}{ Seeded } & Clomazone & 0.8 & 3 & 8 & & $1 \mathrm{~b}$ & $\begin{array}{c}\text { tunting } \\
15\end{array}$ & & 3 & $5 \mathrm{~b}$ & \\
\hline & Ethalfluralin & 1.3 & 9 & 2 & & $8 \mathrm{~b}$ & 2 & & 33 & $50 \mathrm{a}$ & \\
\hline & Pendimenthalin & 0.84 & 17 & 21 & & $35 \mathrm{a}$ & 28 & & 14 & $36 \mathrm{a}$ & \\
\hline & Nontreated & & 0 & 0 & & $0 \mathrm{~b}$ & 0 & & 0 & $0 \mathrm{~b}$ & \\
\hline Transplanted & Clomazone & 0.8 & $14 \mathrm{a}$ & $11 \mathrm{~b}$ & & $0 \mathrm{~b}$ & $14 \mathrm{a}$ & & 3 & 6 & \\
\hline
\end{tabular}

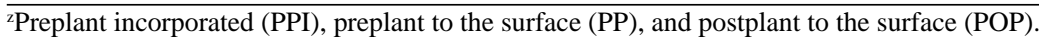

${ }^{\mathrm{y}}$ Mean separation within parameters, columns and planting methods by Fisher's protected LSD test, $P \leq 0.05$. Absence of letters indicates F value was not significant at $P \leq 0.05$. 
that were transplanted after PPI or surface application of 1.2 and $2.4 \mathrm{~kg} \cdot \mathrm{ha}^{-1}$ of ethalfluralin, whereas posttransplant application at the same rates was not injurious.

Pendimethalin. Pendimethalin PPI reduced stand of seeded plots $25 \%$ to $41 \%$, compared with $50 \%$ to $100 \%$ for ethalfluralin (Table 1). While pendimethalin was clearly not as injurious as ethalfluralin at $1.3 \mathrm{~kg} \cdot \mathrm{ha}^{-1}$, the level of injury was not commercially acceptable. The difference in injury observed between these two dinitroaniline herbicides is probably attributable to differences in rate. Ethalfluralin was applied at $1.26 \mathrm{~kg} \cdot \mathrm{ha}^{-1}$, pendimethalin at $0.84 \mathrm{~kg} \cdot \mathrm{ha}^{-1}$. Pendimethalin has injured plants and reduced the stand of cucurbits when applied prior to planting (Darmstadt, 1979; Eshel and Shlevin, 1973; Menges et al., 1973).

Stand of transplanted watermelon was unaffected by pendimethalin PPI, PP, or POP. At the rates used in this experiment, stand reduction was generally greater with pendimethalin than with clomazone, but much less than with ethalfluralin.

\section{Bleaching}

Clomazone. Most clomazone treatments resulted in some bleaching of watermelon foliage ranging from $0 \%$ to $30 \%$ (data not presented). Bleaching was transient, visible only 7-10 d after application, and was never observed on any fruit. Generally, bleaching was more severe following transplanting than seeding (2\% to $30 \%$ and $0 \%$ to $19 \%$, respectively) and appeared to be unrelated to time of application. The primary route of uptake is via the root, and transplants begin absorbing clomazone as soon as roots contact it in soil solution. Boyhan et al. (1995) observed foliar bleaching of seeded plants with clomazone PRE. Other research indicates that the minor bleaching observed immediately after emerge ce of relatively tolerant species is transient and does not affect yield of many crops, including squash (Grey et al., 2000), pumpkin (Barth et al., 1995), pea (Pisum sativum L.) (Boydston and Kraft, 1991), and pepper (Weston and Jones, 1990).

Ethalfluralin and pendimethalin. No chlorosis or bleaching was evident when ethalfluralin or pendimentalin PPI, PP, or POP was applied to either seeded or transplanted watermelon.

\section{Stunting}

Clomazone. Seeded was tolerant of clomazone. No more stunting was observed than in the nontreated control, regardless of time of application (Table 1). Transplanted watermelon was injured by PPI in 1993 and by PP in 1994. However, the injury, 14\% or less, did not affect yield.

Ethalfluralin. Ethalfluralin POP resulted in severe $(33 \%$ to $50 \%)$ stunting of seeded plants (Table 1). Excessive rainfall occurred throughout June 1994 (23.2 cm total). Stand losses were great (47\%) with ethalfluralin POP and virtually all surviving plants were severely stunted. These data indicate that when ethalfluralin is applied at $1.3 \mathrm{~kg} \cdot \mathrm{ha}^{-1}$, subsequent incorporation of the herbicide mechanically, or via precipitation or irrigation will probably lead to moderate-to-severe injury, regardless of method of application (PPI, PP, or POP). Stand loss and injury are proportional to the amount of root and shoot exposure to the herbicide (Kupatt, et al., 1983).

Likewise, transplanted watermelons were severely injured (54\% to $95 \%$ ) by ethalfluralin applied PPI and PP in 1993 and 1994. Transplanting watermelons into soil treated with ethalfluralin PPI provides an even exposure to the roots, allowing more herbicide to be absorbed and resulting in severely stunted plants. Application of ethalfluralin PP to transplanted watermelon, using a slit technique that minimizes soil movement, reduced exposure to the herbicide. However, if ethalfuralin-treated soil is used to fill around the transplant, injury similar to that with PPI treatments will result. Mitchem et al. (1997) reported similar transplant effects with ethalfluralin. Insignificant injury occurred when ethafluralin was applied POP, indicating that exposure to the developing root system is a key factor in determining injury.

Pendimethalin. Although the effects were highly variable and not always significant, pendimethalin PPI, PP, and POP often caused injury to seeded plants. Stunting with PP and POP treatments and some injury with all treatments were observed in 1993 and 1994. Kupatt et al. (1983) also reported that pendimethalin PPI and PP injured seeded cucurbits.

Little stunting was observed following application of pendimethalin PPI, PP, or POP to transplanted watermelon. These data indicate that pendimethalin might be useful for weed control in transplanted watermelon.

\section{Number of cull fruit}

Number of culled watermelons was not affected by herbicide, application timing, or method of plant establishment (data not presented). Where few, or no, culled watermelons were recorded, stand reduction and stunting had occurred, resulting in reduced production.

\section{Fruit number}

Clomazone. The number of marketable watermelons per ha was unaffected by clomazone PPI, PP, or POP or method of stand establishment (seeded or transplanted) (Table 2). In fact, on average, watermelon number was as great or greater for the clomazone treatments than for the nontreated control. In previous research, stand reduction increased with rate of application of clomazone $(0.6,1.1$, and $\left.1.7 \mathrm{~kg} \cdot \mathrm{ha}^{-1}\right)$, resulting in reduced numbers of fruit (Boyhan, et al., 1995). However, our data indicate that both seeded and transplanted watermelons are tolerant of clomazone.

Ethalfluralin. Ethalfluralin PPI and PP reduced fruit number in seeded plants each year. The absence of fruit in many plots corroborated the stand reduction and stunting data previously presented. Stand was highest with the POP treatment and this was reflected in increased fruit production. Mitchem etal.(1997) reported crop injury and reduced watermelon production with all applications of ethalfluralin. Total fruit number of transplanted summer squash also declined following pre- and posttransplant application of ethalfluralin (Precheur, 1983).

Pendimethalin. Fruit number was often reduced as a result of stand reduction and stunting following application of pendimethalin PPI, PP, and POP to seeded plots. Fruit numbers were often greater with pendimethalin PPI than with ethalfluralin PPI. Transplanted watermelon fruit numbers were equivalent to or higher than control values following application of pendimethalin PPI, PP, or POP.

\section{Fruit weight}

Clomazone. Average fruit weight was unaffected by treatments of either seeded or transplanted plants with clomazone PPI, PP, or POP (Table 3). Across application times (PPI, PP, or POP) the average weights were consistently higher than or equivalent to those in other clomazone treatments for both seeded and transplanted plants. Corroborating the observation that early-season bleaching was transient, Boyhan et al. (1995) reported a reduction in fruit weight with direct seeding with increasing rate of application of clomazone ( 0.6 to $\left.1.7 \mathrm{~kg} \cdot \mathrm{ha}^{-1}\right)$. However, the maximum clomazone rate applied in our experiments was $0.84 \mathrm{~kg} \cdot \mathrm{ha}^{-1}$.

Ethalfluralin. Seeded plants were sensitive to ethalfluralin PPI and PP, with fruit weights ranging from 0.7 to $6.5 \mathrm{~kg}$. Stunting and season-long injury were reflected in reduced fruit size. However, ethalfluralin applied POP did not affect weight.

Fruit size was not affected when ethalfluralin was applied to transplanted watermelons. Size was reduced by PPI application of ethalfluralin only in 1994, an excessively wet year. Across years and times of application, fruit weight was greatest with ethalfluralin POP, which is consistent with injury and stand reduction data.

Pendimethalin. Average fruit weight was unaffected by pendimethalin, regardless of application time or planting method, and was greater in plots treated with pendimethalin than in those treated with ethalfluralin.

\section{Yield}

Effects on yield were consistent for 1993 and 1995, but were variable in 1994 when excessive rainfall occurred throughout the season. In addition, nearly $50 \mathrm{~cm}$ of rainfall occurred during a 72-h period 2 weeks prior to harvest period in 1994. Given this variability, few differences were significant.

Clomazone. Yield of seeded plants was equivalent to, or greater than, that of the controls for clomazone PPI, PP, and POP during the 3-year experiment (Table 2). Across years and times of application (data not presented), clomazone treatment produced the highest yields of both seeded and transplanted 
Table 2. Fruit number and yield per ha of seeded and transplanted watermelon as influenced by $\mathrm{PPI}^{z}, \mathrm{PP}^{\mathrm{z}}$, and $\mathrm{POP}^{\mathrm{z}}$ application of herbicides at Plains, Ga., $1993-95$.

\begin{tabular}{|c|c|c|c|c|c|c|c|c|c|c|c|}
\hline \multirow[b]{3}{*}{ Planting method } & \multirow[b]{3}{*}{ Herbicide } & \multirow{3}{*}{$\begin{array}{c}\text { Rate of application } \\
\left(\mathrm{kg} \cdot \mathrm{ha}^{-1} \text { a.i. }\right)\end{array}$} & \multicolumn{9}{|c|}{ Herbicide application } \\
\hline & & & \multicolumn{3}{|c|}{ PPI } & \multicolumn{3}{|c|}{$\mathrm{PP}$} & \multicolumn{3}{|c|}{ POP } \\
\hline & & & 1993 & 1994 & 1995 & 1993 & 1994 & 1995 & 1993 & 1994 & 1995 \\
\hline & & & & & & ruit no/ & (in 10,0 & s) & & & \\
\hline & Ethalfluralin & 1.3 & $0 \mathrm{c}$ & 0 & 2 & $1 \mathrm{a}$ & 0 & $0 \mathrm{~b}$ & 8 & 6 & $14 \mathrm{a}$ \\
\hline & Pendimenthalin & 0.84 & $6 \mathrm{a}$ & 3 & 5 & $0 \mathrm{a}$ & 2 & $1 \mathrm{~b}$ & 7 & 5 & $4 \mathrm{~b}$ \\
\hline & Nontreated & & $8 \mathrm{~b}$ & 10 & 4 & $8 \mathrm{~b}$ & 10 & $4 \mathrm{~b}$ & 8 & 10 & $4 \mathrm{~b}$ \\
\hline \multirow[t]{2}{*}{ Transplanted } & Clomazone & 0.8 & 13 & 14 & $9 \mathrm{~b}$ & $10 \mathrm{~b}$ & 16 & $11 \mathrm{a}$ & 10 & 18 & $12 \mathrm{a}$ \\
\hline & Nontreated & & 11 & 6 & $4 \mathrm{~b}$ & $11 \mathrm{~b}$ & 6 & $4 \mathrm{~b}$ & 11 & 6 & $4 \mathrm{~b}$ \\
\hline \multirow{4}{*}{ Seeded } & Clomazone & 0.8 & $21 \mathrm{~b}$ & 37 & 30 & \multicolumn{3}{|c|}{ - Yield $\left(\mathrm{t} \cdot \mathrm{ha}^{-1}\right)$} & 23 & 50 & 36 a \\
\hline & Ethalfluralin & 1.3 & $0 \mathrm{c}$ & 0 & 7 & $1 \mathrm{a}$ & 0 & $0 \mathrm{~b}$ & 20 & 19 & $40 \mathrm{a}$ \\
\hline & Pendimenthalin & 0.84 & $12 \mathrm{a}$ & 9 & 19 & $1 \mathrm{a}$ & 3 & $3 b$ & 17 & 15 & $10 \mathrm{~b}$ \\
\hline & Nontreated & & $22 \mathrm{~b}$ & 28 & 7 & $22 b$ & 28 & $7 \mathrm{~b}$ & 22 & 28 & $7 \mathrm{~b}$ \\
\hline Transplanted & Clomazone & 0.8 & $35 \mathrm{~b}$ & 50 & $28 \mathrm{~b}$ & $28 \mathrm{~b}$ & $63 \mathrm{~b}$ & $33 \mathrm{a}$ & 26 & 69 & $42 \mathrm{a}$ \\
\hline
\end{tabular}

${ }^{2}$ Preplant incorporated (PPI), preplant to the surface (PP), and postplant to the surface (POP).

${ }^{x}$ Mean separation within parameters, columns, and planting methods by Fisher's protected LSD test, $P \leq 0.05$. Absence of letters indicate F value was not significant at $P \leq 0.05$.

Table 3. Average fruit weight $(\mathrm{kg})$ of seeded and transplanted watermelon as influenced by $\mathrm{PPI}^{\mathrm{z}}, \mathrm{PP}^{\mathrm{z}}$, and $\mathrm{POP}^{\mathrm{z}}$ application of herbicides at Plains, Ga., $1993-95$.

\begin{tabular}{|c|c|c|c|c|c|c|c|c|c|c|c|}
\hline \multirow[b]{3}{*}{ Planting method } & \multirow[b]{3}{*}{ Herbicide } & \multirow{3}{*}{$\begin{array}{c}\text { Rate of application } \\
\left(\mathrm{kg} \cdot \mathrm{ha}^{-1} \text { a.i. }\right)\end{array}$} & \multicolumn{9}{|c|}{ Herbicide application } \\
\hline & & & \multicolumn{3}{|c|}{ PPI } & \multicolumn{3}{|c|}{ PP } & \multicolumn{3}{|c|}{ POP } \\
\hline & & & 1993 & 1994 & 1995 & $\overline{1993}$ & 1994 & 1995 & 1993 & 1994 & 1995 \\
\hline & & & \multicolumn{9}{|c|}{ Weight (kg/fruit) } \\
\hline & Ethalfluralin & 1.3 & 7.5 & $0.0 \mathrm{a}$ & 4.9 & 3.5 & --- & $0.0 \mathrm{~b}$ & 6.7 & 8.3 & $7.8 \mathrm{a}$ \\
\hline \multirow{4}{*}{ Transplanted } & Pendimenthalin & 0.84 & 6.8 & $7.5 \mathrm{~b}$ & 9.5 & 2.0 & 6.3 & $2.1 \mathrm{~b}$ & 7.1 & 8.7 & $7.8 \mathrm{a}$ \\
\hline & Nontreated & & 7.5 & $6.6 \mathrm{~b}$ & 3.6 & 7.5 & 6.5 & $3.6 \mathrm{~b}$ & 7.5 & 6.6 & $3.6 \mathrm{~b}$ \\
\hline & Clomazone & 0.8 & 7.2 & $9.8 \mathrm{~b}$ & $8.8 \mathrm{~b}$ & 7.4 & 10.9 & 8.7 & 7.2 & 10.8 & 9.1 \\
\hline & Nontreated & & 7.6 & $9.1 \mathrm{~b}$ & $7.4 \mathrm{~b}$ & 7.6 & 9.1 & 7.4 & 7.6 & 9.1 & 7.4 \\
\hline
\end{tabular}

${ }^{2}$ Preplant incorporated (PPI), preplant to the surface (PP), and postplant to the surface (POP).

${ }^{y}$ Mean separation within parameters, columns, and planting methods by Fisher's protected LSD test, $\mathrm{P} \leq 0.05$. Absence of letters indicate $\mathrm{F}$ value was not significant at $P \leq 0.05$.

watermelon. Boyhan, et al. (1995) reported that yields of seeded plants fell as rate of application of clomazone PP $(0.6,1.1$, and $\left.1.7 \mathrm{~kg} \cdot \mathrm{ha}^{-1}\right)$ increased. This reduction may be attributed to herbicide injury associated with the higher rate of clomazone used in their study and soil type effects. Loux et al. (1989) reported that soil type does influence clomazone activity, with increased adsorption as clay content increases. Since this study was conducted, another formulation of clomazone (microencapsulated) has been introduced that has demonstrated improved crop safety in cucurbits (Grey et al., 2000).

Yield of transplanted watermelon was not affected by clomazone, regardless of application timing. Across years and application times, clomazone treatment produced yields equal to those obtained with pendimethalin but greater than those following ethalfluralin treatment or no treatment. These data indicate good overall crop safety and weed control, and a wide range of application time with clomazone.

Ethalfluralin. Application of ethalfluralin PPI or PP to seeded plots resulted in severe stand reduction, stunting, and reduced fruit number and yield. Across years and methods of application, yield of seeded plants with ethalfluralin was similar to that with pendimethalin, about one-half that of the control, and about one-fourth that with clomazone. Root injury from PPI or PP treatments of seeded plants was reflected in overall yield. Ethalfluralin POP caused injury to seeded plants, but this did not reduce yield.

Ethalfluralin PPI and PP stunted transplanted watermelons. Yield was highly variable from year to year; however, yield of transplants was reduced by ethalfluralin PPI and PP in 1993 and by PP in 1994. Injury to transplants was less with POP than with PPI and PP applications, and yield was not reduced by ethalfluralin POP. Across years and times of application, yield was greater with ethalfluralin than for the control, but less than with clomazone or pendimethalin.

Pendimethalin. Pendimethalin PP reduced yield of seeded plants, and the effects of PPI and POP applications were variable. Across years and times of application, yield of seeded plants was similar following treatments with pendimethalin and ethalfluralin, whereas controls and plants treated with clomazone were less productive.

Application of pendimethalin PPI, PP, and POP to transplants resulted in yields equivalent to or greater than that of the control. Across years and times of application, transplants treated with pendimethalin or clomazone yielded more than did the controls or those treated with ethalfluralin.

\section{Conclusions}

These studies indicate that application of clomazone PPI, PP, or POP to direct-seeded or transplanted watermelon had little or no effect on stand, stunting, fruit number, or yield. Bleaching of seedlings, seeded and transplanted, occurred with most clomazone treatments but the effect was transient and did not affect yield. Ethalfluralin PPI and PP severely injured both seeded and transplanted watermelon, and reduced yield. Ethalfluralin POP resulted in slight injury and stand reduction but yield was not adversely affected. Application of pendimethalin PPI, PP, and 
POP to direct-seeded plots reduced stand, stunted plants, and reduced yield, but transplants were not affected.

Clomazone at the rate tested was less injurious to seeded and transplanted watermelon than was ethalfluralin or pendimethalin. Based upon injury from ethalfluralin and pendimethalin PPI and PP for a given application timing or establishment method, the rates used to establish seeded plants should be avoided. Ethalfluralin PP can be safely applied to direct-seeded plantings only if the $1.3 \mathrm{~kg} \cdot \mathrm{ha}^{-1}$ rate is used. Pendimethalin PPI, POP, and PP and ethalfluralin PP do not affect transplants.

The data suggest that the effect of these herbicides can be predicted better for transplanted than for seeded plants. This supports further usage of transplants, particularly considering the high costs of many watermelon seed today.

\section{Literature Cited}

Ahrens, W.H. (ed.). 1994. Herbicide handbook. 7th ed. Weed Sci. Soc. Amer., Champaign, Ill.

Barth, M.M., L.A. Weston, and H. Zhuang. 1995 Influence of clomazone herbicide on post-harvest quality of processing squash and pumpkin. J. Agr. Food Chem. 43:2389-2393.

Boydston, R.A. and J.M. Kraft. 1991. Differential response of pea lines to clomazone. Research progress report-Western Society of Weed Science. Reno, Nev.

Boyhan, G.E., S.P. Kovach, J.D. Norton, B.R. Abrah- ams, M.H. Hollingsworth, and J.M. Dangler. 1995. Pre-emergent herbicides for cantaloupe and watermelon. J. Veg. Crop Prod. 1:79-94.

Darmstadt, G. 1979. Weed control in selected cucurbits with ethalfluralin. Proc. California Weed Conf. 1979:43-50.

Eshel, Y. and E. Shlevin. 1973. Toxicity of dinitroaniline herbicides to watermelons. J. Amer. Soc. Hort. Sci. 98:483-485.

Frost, D.J., S.F. Gorske, and E.E. Wittmeyer. 1983. Summer squash tolerances to selected herbicides. HortScience 18:911-912.

Glaze, N.C. 1975. Weed control in cucumber and watermelon. J. Amer. Soc. Hort. Sci. 100: 207_ 209

Grey, T.L., D.C. Bridges, and D.S. NeSmith. 2000. Tolerance of cucurbits to the herbicides clomazone, ethalfluralin, and pendimenthalin. I. Summer squash. HortScience 35:632-636.

Kupatt, C., R.D. Ilnicki, and D.B. Vitolo. 1983. Weed control in winter squash with some old and new herbicides. Proc. Northeastern Weed Sci. Soc. 37:145-149.

Langston, S.J., R.G. Harvey, and J.W. Albright. 1997. Efficacy of clomazone applied at various timings in soybean (Gylcine max). Weed Tech. 11:105-109.

Loux, M.M., R.A. Liebl, and F.W. Slife. 1989. Adsorption of clomazone on soils, sediments, and clays. Weed Sci. 37:440-444.

MacDonald, G.E. 1999. Commercial vegetablesweed control in 1996. Georgia pest control handbook. Coop. Ext. Serv. Univ. of Georgia College of Agr. and Environ. Sci., Athens.

Menges, R.M., T.D. Longbrake, and S. Tamez. 1973. Effect of soil incorporation on selectivity, movement, and persistence of herbicides in watermelon plantings. J. Amer. Soc. Hort. Sci. 97:168-172.

Mitchem, W.E., D.W. Monks, and R.J. Mills. 1997. Response of transplanted watermelon (Citrullus lanatus) to ethalfluralin applied PPI, PRE, and POST. Weed Tech. 11:88-91.

Mizelle, W.O. 1999. Georgia vegetable acreage estimates (AGECON 93-027). Coop. Ext. Service. U.S. Dept. of Agr. Univ. of Georgia College of Agr. and Environ. Sci. Athens.

Monaco, T.J. and W.A. Skroch. 1980. A summary of ethalfluralin performance on cucurbits. Proc. Southern Weed Sci. Soc. 33:71-80.

Monks, D.W. and J.R. Schultheis. 1998. Critical weed-free period for large crabgrass (Digitaria sanguinalis) in transplanted watermelon (Citrullus lanatus). Weed Sci. 46:530-532.

NeSmith, D.S., G. Hoogenboom, and D.V. McCracken. 1994. Summer squash production using conservation tillage. HortScience 29:2830.

Porter, W.C. 1990. Clomazone for weed control in sweet potatoes (Ipomoea batatas). Weed Tech. 4: 648-651.

Precheur, R.J. 1983. Effect of PRE and POST planting ethalfluralin application in transplanted summer squash. Proc. Northeastern Weed Sci. Soc. 37:219-222.

U.S. Dept. of Agriculture. 1999. AMS Watermelon Research and Promotion Plan. Research and Promotion Branch, Fruit and Vegetable Programs, Agr. Mktg. Serv., U.S. Dept. Agr., Washington, D.C.

Weston, L.A. and R.T. Jones. 1990. Tolerance of transplanted bell peppers (Capsicum anпиит) to clomazone and diethatyl applied premergent. App. Agr. Res. 5:13-16. 